\title{
In Vivo Antimalarial Activity of Ethanol Extract of Carthamus Tinctorius L. Flowers Against Plasmodium Berghei Strain Anka In Male Mice $\mathrm{Balb} / \mathrm{C}$
}

\author{
Rini Hamsidi ${ }^{1}$, Aty Widyawaruyanti ${ }^{2}$, Achmad Fuad Hafid $^{2}$, Wiwied Ekasari ${ }^{2}$, Henny Kasmawati ${ }^{1}$, \\ Nur Illiyyin Akib ${ }^{1}$, Wahyuni $^{1}$, and M.Hajrul Malaka ${ }^{1}$
}

\begin{abstract}
Malaria is infectious disease that caused by Plasmodium parasite. The problem of malaria restraint is the parasite resistance to antimalarial medicines. The aim of this study was to know the inhibition effect of ethanol extract of C.tinctorius Linn flowers in male mice BALB/C that infected by Plasmodium berghei strains ANKA. Antimalarial Activity of ethanol extract of C.tinctorius flowers was measured by Peter Test method. The extract was given by oral for 4 days respectively. Parasitemia percentage that observed for 7 days. The treatment groups of mice were divided into 5 groups; Negative group, and 4 treatment groups with dose $10 \mathrm{mg} / \mathrm{kgBW} ; 100 \mathrm{mg} / \mathrm{kgBW} ; 250 \mathrm{mg} / \mathrm{kgBW}$; and 500 $\mathrm{mg} / \mathrm{kgBW}$. The result of this study showed that doses of 10 $\mathrm{mg} / \mathrm{kgBW} ; 100 \mathrm{mg} / \mathrm{kgBW} ; 250 \mathrm{mg} / \mathrm{kgBW}$; and $500 \mathrm{mg} / \mathrm{kgBW}$ could inhibit the the parasite growing by $41,51 \% ; 63,16 \% ; 69,02 \%$ and $51,89 \%$ respectively. Result of the data analyzed showed that 250 $\mathrm{mg} / \mathrm{kgBW}$ treatment group had the best antimalarial activity. According to Probit analysis showed that antimalaria activity of Ethanol Extract of $C$. tinctorius flower in mice that infected with $P$. berghei strain ANKA had $\mathrm{ED}_{50}$ value with $24,79 \mathrm{mg} / \mathrm{kgBW}$.
\end{abstract}

Keywords - Antimalarial, Carthamus tinctorius L., $\mathrm{ED}_{50}$, Plasmodium berghei strain ANKA

\section{INTRODUCTION}

Malaria is an infection disease caused by parasite Plasmodium was transmitted through of a female Anopheles mosquito bites. Malaria is still a serious public health problem. According to the World Health Organization (WHO), malaria attacked the 108 countries in the world in 2008. According to WHO data, 214 million cases of malaria worldwide and caused more than 500 thousand deaths. The most of malaria cases and deaths are found in Africa and some countries in Asia, Latin America, the Middle East and Europe. Every 45 seconds a child in Africa dies from the disease malaria [1].

Malaria cases in Southeast Sulawesi on years (2008-2012) tended to increase, in 2008 the number of cases 671 (API 0.30 ), in 2009 the number of cases 488 (API 0.21), while in 2010 the number of cases in 2385 (API 1.04), in 2011 the number of cases 3,323 (API 1.45) and in 2012 a number of 2,015 cases (API 0.87). Malaria morbidity rate revealed to be high if the numbers Annual Parasite Incidence (API)> 5 per 1,000 population, was $1-4$ per 1000 population and low when $<1$ per 1,000 population.

Faculty of Pharmacy Halu Oleo University Kendari South East, Indonesia
Thus Southeast Sulawesi was still included in the category of malaria endemicity Medium [2]

Efforts to control against this disease had been carried out, but the morbidity and mortality of malaria in some countries is still high. The spread of antimalarial drug resistance to all first layer (front-line antimalarial compound) used in the treatment and prevention of malaria has caused many problems in malaria control programs. Along with the successful attempt yet to find the ideal malaria vaccine, the research activities aimed at the discovery of new drugs and identify targets for chemotherapeutic intervention remains a primary goal in the fight against malaria. This led to the search of new compounds as antimalarial drugs either from natural materials and synthetic results continue to be made. The new drugs are affordable for the local transmission of malaria is absolutely necessary if the impact of malaria would like to be reduced or even overcome [3].

Medicinal plants in Indonesia can be used as an antimalarial, which is antiplasmodial and also are increasing the body's resistance to malaria disease. Research on natural product in an effort to discover new antimalarial compounds intensively conducted by researchers in the world in the last decade. These developments have prompted exploration of other medicinal plants as well as from Indonesia, which is thought to contain the active antimalarial compounds. Now it has known some new compound isolated from the medicinal plant alkaloids, terpenoids, flavonoids, limonid, peptides, quinone, coumarin, anthraquinone, kalkon and xanton that have antimalarial activity in vitro and in vivo [4].

Kasumba Turate (Carthamus tinctorius L.) is a plant endemic to Sulawesi, which is usually used to treat the disease sarampa, measles, and chickenpox. Akib, et al., 2014 [5] has conducted research using a water extract, ethanol extract and methanol extract showed that the ethanol extract can inhibit the growth of Plasmodium falciparum D37 and IC50 value of $1: 06 \mathrm{mg} / \mathrm{mL}$, so the ethanol extract of C. Tinctorius L. has the potential to developed into antimalarial drugs. Tests in vivo antimalarial selected with the expectation results obtained can be further illustrate the real conditions of the parasite in the host body as compared with in vitro activity test. In vivo activity test using Plasmodium berghei ANKA strain because it is a perfect model for testing. This is due to P. berghei is the subject of the similarities in parasites that infect humans [6].

Based on the above background, the research will be conducted test antimalarial activity of the ethanol extract of 
flowers kasumba turate (C. tinctorius L.) to infected mice with P. berghei ANKA strain.

\section{PROCEDURE}

\section{A. Plant Material}

Flowers of kasumba turate (Carthamus tinctorius Linn) were collected from Bone, a regency in South Sulawesi, and have previously been determined by Purwodadi's LIPI in Pasuruan.

\section{B. Extraction}

The flowers of kasumba turate (Carthamus tinctorius Linn) were ground into powder weighed 290 grams. Simplicia powder was macerated in ethanolic and methanolic liquid for $3 \times 24$ hours. The filtrates were collected and evaporated by using evaporator, reducing pressure until thick extract was obtained.

The powder extracted from the flowers of kasumba turate (Carthamus tinctorius Linn) was macerated in ethanolic liquid. Two hundred and ninty grams of the powder of kasumba turate flower were extracted by using ethanol, resulting in 70.6 grams of thick yellow-brownish ethanolic extract with $24.35 \%$ of yield.

\section{In Vivo Antimalarial Activity Assay}

Determination of the Effective Dose ethanol extract of C. tinctorius $\mathrm{L}$. flower in vivo in mice.

The determination of an effective dose of C. tinctorius $\mathrm{L}$. based survey ethnobotany antimalarial activity at $10 \mathrm{mg} / \mathrm{kg}$ in mice, $100 \mathrm{mg} / \mathrm{kg}$ in mice, $250 \mathrm{mg} / \mathrm{kg}$ in mice and $500 \mathrm{mg}$ / $\mathrm{kg}$ body weight of mice orally for 4 consecutive days (Munoz, et al. 2000). Smear dried at room temperature, fixed with methanol, then once dry stained with Giemsa and counted under a microscope parasitemianya with 1000 times magnification. Calculations performed on 5000's erythrocytes.

Donor Mice infection with $P$. berghei ANKA strain infection donor mice were performed which injects infected blood P. berghei ANKA strain on the body of the donor mice. The materials used to infect mice are deposits frozen donor infected erythrocytes P. berghei ANKA strain. Deposits frozen erythrocytes were increased temperature by warmed with palms while playing around to fit the body temperature of mice. After that, the erythrocytes injected into the body of mice intraperitoneally (injected in the stomach cavity) by 200 $\mathrm{mL}$.

\section{Data Analysis}

The data obtained from in vitro antimalarial activities assay above is in the form of number of parasite-infected erythrocytes (counted on around 5000 erythrocytes) were subsequently converted into parasitemia levels (percent parasitaemia) and the percent inhibition of the test substance on the growth of the parasite.
Percent parasitaemia calculated by the formula:

$$
\% \text { Parasitemia }=\frac{\sum \text { infected erythrocytes }}{\text { The number of erythrocytes }}
$$

The percentage inhibition of parasite growth is calculated using the formula:

$$
\% \text { Inhibition }=100 \%-\left(\frac{\mathrm{Xp}}{\mathrm{xk}}\right) \times 100 \%
$$

Based on the data about the inhibition and concentration of the tested materials, $\mathrm{IC}_{50}$, or the concentration of test materials that inhibit parasite growth by $50 \%$, were then calculated by using the probity analysis

\section{RESULT}

In vivo antimalarial assay of Plasmodium berghei strain ANKA was conducted on the ehanolic extracts of kasumba turate flower. Results of this test can be seen on the table and figure below. As can be seen, ethanolic extracts had an inhibitory power over the growth of Plasmodium berghei strain ANKA. The test on $100 \mu \mathrm{g} / \mathrm{mL}$ concentration show that,compared to the negative control, the inhibitory power of ethanolic and methanolic extracts were $95.97 \%$ and $62.39 \%$ respectively. This inhibitory power reduced as tested concentration was also reduced, indicating that the inhibitory power of ethanolic and methanolic extracts depend on concentration

TABLE I. PERCENT GROWTH AND The INHIBITION OF THE ETHANOL

\begin{tabular}{|c|c|c|c|c|c|}
\hline \multicolumn{2}{|c|}{$\begin{array}{c}\text { Dose } \\
(\mathrm{mg} / \mathrm{kgBB})\end{array}$} & $\begin{array}{c}\text { percent } \\
\text { growth }(\%)\end{array}$ & $\begin{array}{c}\text { Percent } \\
\text { growth } \\
\text { average }(\%)\end{array}$ & $\begin{array}{c}\text { Percent } \\
\text { inhibition }(\%)\end{array}$ & $\begin{array}{c}\text { Percent } \\
\text { inhibition } \\
\text { average }(\%)\end{array}$ \\
\hline \multirow{5}{*}{$\begin{array}{l}\mathbf{K} \\
(-)\end{array}$} & I & 6,31 & \multirow{5}{*}{6,25} & \multirow{5}{*}{ - } & \multirow{5}{*}{ - } \\
\hline & II & 8,34 & & & \\
\hline & III & 5,01 & & & \\
\hline & IV & 5,12 & & & \\
\hline & $\mathbf{V}$ & 6,5 & & & \\
\hline \multirow{5}{*}{10} & I & 2,73 & \multirow{5}{*}{3,69} & 56,32 & \multirow{5}{*}{41,51} \\
\hline & II & 6,19 & & 0,96 & \\
\hline & III & 5,25 & & 16 & \\
\hline & IV & 2,76 & & 55,91 & \\
\hline & V & 1,54 & & 75,36 & \\
\hline \multirow{5}{*}{100} & I & 2,94 & & 52,96 & \multirow{5}{*}{63,16} \\
\hline & II & 2,75 & & 56 & \\
\hline & III & 1,68 & 2,32 & 73,12 & \\
\hline & IV & 2,12 & & 66,08 & \\
\hline & $\mathbf{V}$ & 2,02 & & 67,68 & \\
\hline \multirow{5}{*}{250} & I & 0,59 & & 90,56 & \multirow{5}{*}{69,02} \\
\hline & II & 1,56 & & 75,04 & \\
\hline & III & 1,94 & 2,09 & 68,96 & \\
\hline & IV & 3,24 & & 48,16 & \\
\hline & $\mathbf{V}$ & 2,35 & & 62,4 & \\
\hline \multirow{2}{*}{500} & I & 2,86 & \multirow{2}{*}{3,02} & 54,24 & \multirow[b]{2}{*}{51,89} \\
\hline & I & 350 & & & \\
\hline
\end{tabular}
EXTRACT OF C. Tinctorius L. Flower At VARIOUS DOSES From H1-H4 
For the negative control parasitic growth on average of $\mathrm{H} 1$ $\mathrm{H} 4$ reached $6.25 \%$, while the ethanol extract of $\mathrm{C}$. tintorius $\mathrm{L}$. with a dose of $10,100,250$ and $500 \mathrm{mg} / \mathrm{KgBW}$ row is $3.69 \% ; 2.32 \% ; 2.09 \%$ and $2.98 \%$. The percentage of inhibition are presented in Table 6.

The lower of percentage parasitemia is shown greater the percentage of inhibition. The percentage inhibition of $\mathrm{H} 1-\mathrm{H} 4$ for the ethanol extract dose of 10, 100, 250 and $500 \mathrm{mg} / \mathrm{kg}$ / day respectively $41.51 \% ; 63.16 \% ; 69.02 \%$ and $51.89 \%$. At a dose of $500 \mathrm{mg} / \mathrm{KgBW}$ the highest doses but has a smaller percent inhibition of a dose of $250 \mathrm{mg} / \mathrm{KgBW}$. It was alleged that these mice overdose and possible substances contained in the extract becomes toxic thus damaging the organ, tissue or impair the performance of the cells in the mice, thereby triggering the growth of malaria parasites.

Table 2. Analysis SPSS data

95\% Confidence Limits for dosis $\quad 95 \%$ Confidence Limits for $\log (\text { dosis })^{\prime}$ Probability Estimate Lower Bound Upper Bound Estimate Lower Bound Upper Boun

\begin{tabular}{cccccc}
\hline .010 & .000 &. &. & -7.640 &. \\
.020 & .000 &. &. & -6.581 &. \\
.030 & .000 &. &. & -5.909 &. \\
.040 & .000 &. &. & -5.404 &. \\
.050 & .000 &. &. & -4.993 &. \\
.060 & .000 &. &. & -4.643 &. \\
.070 & .000 &. &. & -4.337 &. \\
.080 & .000 &. &. & -4.062 &. \\
.090 & .000 &. &. & -3.812 &. \\
.100 & .000 &. &. & -3.582 &. \\
.150 & .002 &. &. & -2.630 &. \\
.200 & .013 &. &. & -1.874 &. \\
.250 & .060 &. &. & -1.225 &. \\
.300 & .228 &. &. & -.642 &. \\
.350 & .791 &. &. & -.102 &. \\
.400 & 2.574 &. &. & .411 &. \\
.450 & 8.061 &. &. & .906 &. \\
.500 & 24.795 &. &. & &. \\
\hline
\end{tabular}

This inhibition percentage value is used as the basis for establishing antiplasmodium activity in vivo by determining the $\mathrm{ED}_{50}$ value using probit analysis program SPSS. $\mathrm{ED}_{50}$ value indicates the magnitude of the dose that can inhibit $50 \%$ growth of P. berghei ANKA strain of the total population. Based on probit analysis (Table 2), $\mathrm{ED}_{50}$ values obtained ethanol extract of C. tinctorius L. interest of $24.79 \mathrm{mg} /$ $\mathrm{KgBW}$. This value when viewed in the classification as a potential antimalarial included in the excellent category.

Antiplasmodium activity in vivo grouped into very good when $\mathrm{ED}_{50}$ values $<100 \mathrm{mg} / \mathrm{kg} / \mathrm{day}$, both categories when the $\mathrm{ED}_{50}$ values between $101-250 \mathrm{mg} / \mathrm{kg} / \mathrm{day}$, the medium category when $\mathrm{ED}_{50}$ values between $251-500 \mathrm{mg} / \mathrm{kg} /$ day and not active when $>500 \mathrm{mg} / \mathrm{kg} /$ day [7]. The use of chloroquine as a positive control is better at inhibiting the growth of P. berghei ANKA strain compared with the ethanol extract of flowers of $\mathrm{C}$. tinctorius $\mathrm{L}$. It is seen from the $\mathrm{ED}_{50}$ value of chloroquine at $0.1561 \mathrm{mg} / \mathrm{kg}$ (Raharjo, et al., 2014). $\mathrm{ED}_{50}$ value of the ethanol extract of flower Carthamus L. tintorius in the category very well. This means that the ethanol extract of flower Carthamus L. tintorius potential as antimalarial drug material and can be used as a new malaria treatment or as combination with another antimalarial drugs.

\section{CONCLUSION}

The ethanol extract flower kasumba Turate (C. tinctorius L.) can inhibit the growth of P. berghei ANKA strain in mice in vivo. Based on the analysis of probit $\mathrm{ED}_{50}$ values obtained ethanol extract flower kasumba Turate (C. tinctorius L.) amounted to $24.79 \mathrm{mg} / \mathrm{KgBW}$ in inhibiting the growth of P. berghei ANKA strain in mice on antimalarial vivo test .

\section{ACKNOWLEDGMENT}

I would like to express my deep acknowledgements to Prof. Dr. Sahidin, M.Si., as a dean of Faculty of Pharmacy, Halu Oleo University and Faculty of Pharmacy Airlangga University. Thank you to Ministry of Research, technology and higher education on research grants between universities.

\section{REFERENCES}

[1] World Health Organization. 2015. Global Report on Antimalarial Drug Efficacy and Drug Resistance: 2000-2010. WHO Geneva. Switzerland.

[2] Dinkes Sultra, 2012, Profil Kesehatan Provinsi Sulawesi Tenggara Tahun 2012. Dinkes Sultra, Kendari.

[3] Widyawaruyanti, A., Zaini, N.C., Syafruddin., 2011. Mechanisms and antimalarial activity of compounds flavonoids isolated from Cempedak (Artocarpus champeden). JBP Vol. 13, No. 2

[4] Batista R, Silva AJ Jr., de Oliveira. 2009. AB: Plant-derived antimalarial agents: new leads and efficient phytomedicines. Part II. Non-alkaloidal natural products. Molecules, vol 14:3037-3072. https://doi.org/10.3390/molecules14083037

[5] Akib, N.I., Hamsidi R., Wahyuni, 2015, test antimalarial activity Flower Extract Carthamus tinctorius L. In vitro cultures of Plasmodium falciparum, Pharmauho, Vol. 1 No. 1

[6] Raharjo, A., Ekasari, W., Hafid, A.F., 2014. Test Air Leaf Extract antimalarial activity Johar (Cassia siamea Lamk) Against Plasmodium berghei In In vivo. Journal of Pharmacy and Pharmaceutical Sciences Indonesia, Vol. 1 No. 1

[7] Isa., Rinidar., Sugito. 2012. Activities Antiplasmodium Leaves Sernai (Wedelia biflora) Based on Evaluation of Kidney and Liver Function in Mencityang infected with Plasmodium berghei. Veterinary Journal. Vol. 13 No. 2 